\title{
Bedømmelsens kompleksitet
}

Elsa Schmidt er cand. psych., autoriseret psykolog, selvstendig konsulent - siden 1998 censorformand for det landsdakkende censorkorps i psykologi ved universiteterne.

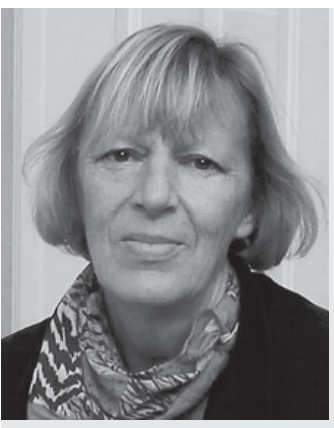

Elsa Schmidt er uddannet cand. psych. fra Københavns Universitet og fungerer i dag som praktiserende psykolog og selvstændig konsulent med eget firma. I perioden 1979-1982 var hun formand for Dansk Psykologiforening og har siden været forstander og rektor for en række institutioner, herunder uddannelsesinstitutioner. Hun har desuden mange års erfaring som censor ved psykologiuddannelserne i Danmark og har siden 1998 været censorformand for det landsdækkende censorkorps i psykologi ved universiteterne.

I artiklen sammenholdes hverdagens bedømmelser af mennesker med de bedømmelser, der sker ved eksaminer. Der er forskelle på grund af det retlige grundlag, men også ligheder. Konkrete erfaringer med klage- og ankesager gennem 8 à fra faget psykologi på landsplan opsummeres. Nogle få praktiske losninger beskrives.

I alle samfund sker bedømmelser hver dag. De sker på gaden - de sker i private sammenhænge - de sker i arbejdsmæssige sammenhænge. Bedømmelser foretages uvilkårligt af hver enkelt af os hver dag.Vi kan mærke, at det sker. Både når vi selv bedømmer nogen, og når andre bedømmer en. Typisk vil en sådan hverdagsbedømmelse fornemmes som uklar, diffus og aldeles umulig at forholde sig konkret til, fordi den typisk sker halvformuleret - og dermed er mangetydig. Det gælder både bedømmelser, der hælder til den positive side, og dem, der hælder til den kritiske side. De uformulerede, halvformulerede, bedømmelser i hverdagslivet er anledning til mange skænderier og konflikter. Og tilsvarende anledning til mange helt urealistiske forestillinger om eget positive værd i andres øjne. Det er sjældent, at hverdagens bedømmelser har alvorlige praktiske konsekvenser.

Noget andet er eksamen. Ved eksamen er der ydre kriterier at forholde sig til, og menneskers faglige fremtid er på spil, og andre menneskers tiltro til den kunnen der fremgår af eksamensbeviset er også på spil. Her er vi principielt inde $\mathrm{i}$ det retlige system.

Bedømmelser i hverdagslivet er til konstant undersøgelse og debat i offentligheden, men sjældent direkte mellem parterne, fordi der ingen stabil målestok er for dem - den forandrer sig hele tiden, på de områder, der særligt er under debat. For eksaminer er også det retlige grundlag under konstant offentlig debat, og opleves dermed måske lige så uklart som hverdagslivets bedømmelser. Både i hverdagslivet og i eksamenssammenhæng er oplevelsen af, at bedømmelsen er retfærdig afgørende for, om man godtager bedømmelsen. Oplevelsen af risiko for forskelsbehandling er kernepunktet for forståelsen af det sociale fænomen: bedømmelse af andre mennesker.

\section{Eksamens retlige grundlag}

I dag er eksamens retlige grundlag fastlagt gennem fire regelsæt. Det ene er den lov, den pågældende uddannelse er oprettet under, hvor der er en kort formålsparagraf. Det andet er eksamensbekendtgørelsen, som fastslår, at uddannelsen skal udarbejde en studieordning, hvor de faglige krav til de enkelte eksamensenheder beskrives, ligesom institutionsansvar, bedømmeransvar og studerendes rettigheder beskrives. Det tredje er studieordningens beskrivelser af de faglige krav til de enkelte eksamensenheder. Og det fjerde er vejledende eller obligatorisk pensum for de enkelte eksamensenheder.

Imidlertid forekommer der misforståelser og uklarheder, både i positiv og negativ retning, også i denne sammenhæng, som er reguleret tydeligt retligt i modsætning til bedømmelserne $\mathrm{i}$ det almindelige hverdagssamkvem. De kan opstå på forskellige måder, og i forskellige situationer - før bedømmelsen, ved selve prøven, og ved rolleuklarhed i bedømmelsen. Det beskrives nedenfor kortfattet. 


\section{Før bedømmelsen}

Der er undervisning, og der er pensum der skal læses. Undervisere har traditionelt $\mathrm{i}$ dette land metodefrihed og tankefrihed - også i forhold til traditionen i det pågældende fag. Ofte vil underviserens entusiasme og kreativitet omkring rammerne for traditionen afspejle sig hos de studerende. Det kan virke gensidigt forstærkende. Entusiasme og kreativitet kan derfor føre til oplevelse af, at gamle bastioner kan væltes (hvad de kan, og det sker). Men processen er langsom, så det kan ske, at man tror de er væltet, før de reelt er væltet. Pensum defineres i nogle studier suverænt af den enkelte underviser, men godkendes centralt $-\mathrm{i}$ andre fastlægges det centralt. Studieordninger fastsættes af studienævnet, men fortolkes i daglig praksis af den enkelte underviser.

Regelsættet forudsætter, at mennesker handler - helt automatisk, og uden særskilt vejledning og kontrol - loyalt i forhold til det givne regelsæt. Men netop undervisning forudsætter kreativitet og nysgerrighed hos både undervisere og studerende for at sikre den åbne dialog, der i dag er anerkendt som den bedste måde at skabe ny viden på. Der er derfor en risiko for konflikt mellem en udviklende pædagogisk praksis og den efterfølgende bedømmelse ved en prøve, hvis den åbne og dialogmindede underviser samtidig ikke er særdeles opmærksom på regelsættet, der forandrer sig forholdsvis langsomt.

\section{Bedømmelsens ramme}

Ved mindst $1 / 3$ af prøverne skal der medvirke beskikkede censorer. Det betyder, at der er to personer, der skal samarbejde om bedømmelsen, og at den ene ikke er en del af det lokale faglige miljø, men er »tilsynsførende og medbestemmende« på samme tid.

Censor har principielt kun de ydre, skriftligt formulerede regelsæt at forholde sig til, og kender ofte ikke de interne faglige nybrud på det pågældende universitet. Eksaminator har været part $i$ en måske kreativ udviklingsproces sammen med kolleger og hold, og har måske flyttet sig lidt i forhold til regelsættet, uden helt at være opmærksom på det.

Sådanne to personer skal finde enighed om bedømmelsen, med fælles ansvar for den kommende kandidats faglige lødighed. Realiteten er, at langt de fleste bedømmelser i faget psykologi sker glidende, og i seriøs konsensus. Kun ca. 2,5 \% af samtlige eksaminer (herunder også dem med rent intern bedømmelse) fører til klager. Og kun knap $1 \%$ i alt fører til ankesager - dvs. alvorlige klager, hvor det skal undersøges og afgøres, om alt er gået retmæssigt for sig.

Vi står derfor med noget, der kunne ligne et paradoks: at konsensus mellem sådanne helt uafhængige personer ser ud til at være en form for normaltilstand. Tilsvarende ser det ud til, at de studerende som den tredje og helt uafhængige part også i vidt omfang tilslutter sig denne konsensus.
Realiteten er, at langt de fleste bedømmelser sker i det faglige rum, jeg foretrækker at kalde "den akademiske konsensus". Andre ville måske bruge betegnelsen "form vs. indhold«. Essensen er imidlertid en udbredt enighed om kriterier for analyse, argumentation og perspektivering $\mathrm{i}$ forhold til andre teoretiske tankegange end de af den studerende foretrukne og valgte. Den akademiske konsensus viser sig også ved, at bedømmerne respekterer den studerendes valg af teoretiske retninger - også i tilfælde, hvor deres egne foretrukne teoretiske retninger er andre.

\section{De få konfliktområder}

Der findes konflikter. Både mellem bedømmerne indbyrdes og mellem bedømmerne og de bedømte studerende. De viser sig kun i et fătal af eksaminationerne, og når de er der, ser de ud til at angå helt principielle forhold, langt de fleste af dem. De er derfor interessante at belyse for at få en fornemmelse af, hvad der kan gøres for at forebygge sådanne konflikter, eller for at opløse dem til en fælles organisatorisk læreproces.

I faget psykologi har der nu i snart 8 år været en database, der sammenfatter alle ankesager. Det er blevet til i alt 230 her pr. 1. november 2005. Det er en oversigt, der omfatter alle de 5 institutioner, der har haft det fælles censorkorps siden 1998 (bortset fra en enkelt institution, der først kom til for 2 år siden).

I alle ankesager klages over bedømmelsen - at karakteren er for lav (også i en del tilfælde, hvor der er givet 10). I næsten $2 / 3$ af ankesagerne er begrundelsen for den for lave vurdering en tvivl om, om der er bedømt retfærdigt i forhold til studieordningens faglige krav, og i nogle få tilfælde også med påvisning af, at en forkert studieordning var lagt til grund for bedømmelsen. I disse tilfælde klages der også over eksaminationsgrundlaget, selv om det ikke altid fremgår eksplicit af klageteksten. Kun i få tilfælde (knap 1/4) klages der over eksamensforløbet - dvs. typisk over en mundtlig eksamens gennemførelse, eksamensspørgsmålenes kvalitet, relevans for pensum og den studerendes mulighed for at vise sin viden. Det er forskellige problemer, som skal løses på forskellige måder.

\section{Principielt forskellige roller}

Det er en særegen social situation man som bedømmere og studerende begiver sig ud i, når der skal vurderes en eksamenspræstation. De tre parter har principielt forskellige formelle roller og opgaver i bedømmelsen, og har forskellige forudgående relationer til hinanden. De forskellige roller og de forskellige forudgående indbyrdes relationer kan indvirke på bedømmelsen. På vidt forskellige måder.

Den studerendes opgave er at stille sig til rådighed for vurdering af sin kunnen i det akademiske samfund. 
Skriftligt eller mundtligt. Rollen er modtagende og bidragydende i forhold til krav stillet udefra, der ikke kan anfægtes. Er der tale om en gruppe, er denne gruppes opgave yderligere kompleks, i og med at hvert enkelt gruppemedlem skal sikre at dettes bidrag er synligt og tilgængeligt for individuel bedømmelse.

Typisk vil studerende og eksaminator kende hinanden $i$ forvejen gennem et undervisningsforløb, hvor der kan have været debatter og holmgange på et ligeværdigt niveau. Når eksamen finder sted, er ligeværdigheden ændret afgørende. Ofte vil eksaminator og studerende kende hinanden yderligere igennem et tæt fagligt vejledningsforløb ved opgaveskrivning. Rolleskift for både studerende og eksaminator er derfor betydeligt - fra ligeværdig støtte, coach og vejledning, til nøgtern og uafhængig bedømmelse.

Eksaminators opgave er sammen med censor at vurdere den præstation, der er leveret af den/de studerende. Der er bedømmerpar, hvor eksaminator og censor aldrig før har mødtes - og bedømmerpar, der har kendt hinanden, fagligt i en årrække.

Til de to af rollerne, med en tidligere indbyrdes anderledes rollerelation, der nu er radikalt ændret, kommer så den tredje rolle til i form af en fagperson, der intet konkret kendskab har til disse to rolleparters tidligere indbyrdes forhold. Denne tredje parts introduktion i forholdet er netop begrundet i dennes uvildighed, uden kendskab til forudgående processer og samarbejdsforhold. En form for revisor, der vurderer og bedømmer "samarbejdsregnskabet".

For to af disse roller (eksaminator og studerende) vil kvaliteten af det tidligere kendskab til hinanden kunne spille afgørende ind i forstålsen af det betydelige rolleskift, begge skal indstille sig på. Hvis eksaminator ikke har været vejleder ved opgaven, men kun forelæser, har den studerende typisk en ensidig rolleforventning til eksaminator - en rolleforventning, der tager udgangspunkt $\mathrm{i}$ både det faglige indhold $\mathrm{i}$ forelæsningerne, og den måde eksaminator besvarer spørgsmål fra forsamlingen på. Den tredje part (censor) kan også have et tidligere kendskab til eksaminator, og dette kendskab kan - på godt og ondt - også spille ind i dennes rolleforvaltning ved bedømmelsen.

Rygter om censorernes forskellige faglige standpunkter, deres mildhed i bedømmelsen, og deres måde at optræde på ved feedback eller mundtlig eksamination, vil også spille ind i den studerendes oplevelse af, hvad det er for et samlet "rollesæt" denne indtræder i ved bedømmelsen.

For alle tre parter er der derfor tale om rolleforvaltning, hvor de faktisk forekommende forventninger på forhånd er relativt uklare, bestemt som de ikke sjældent kan være af forhold, der er selve bedømmelsen uvedkommende. De vedkommende forhold er alene de formelle regelsæt.

Både institutionen, de studerendes organisation og censorformandskabet (de tre formelle aktører omkring eksamenshandlingen) har til opgave at tydeliggøre, at sådanne problemer kan opstå - og bidrage til at få dem afhjulpet på måder, der lokalt er funktionsduelige. Og blive ved med at holde øje med, om der kan gøres noget bedre. Rollekonflikten vil være der - altid. Den kan ikke fjernes.

\section{"Akademisk konsensus«?}

I opridsningen af bedømmelsens ramme anvendte jeg afslutningsvis ukommenteret vendingen makademisk konsensus «. Det er ikke et begreb, der er afgrænset og defineret $\mathrm{i}$ videnskabelige værker. Men gentagne gange har jeg været nødt til både mundtligt og skriftligt at forsøge at uddybe, hvad dette uventede fænomen kunne dække over i et fag, hvor teoretiske retninger traditionelt strides om ære og forrang, og hvor langt hovedparten af prøverne indebærer, at der skal foretages faglige skøn over kvaliteten af et komplekst sprogligt indhold (skriftligt eller mundtligt).

Som jeg ser det, er akademisk konsensus en praktisk enighed - helt på tværs af konkurrerende teorier, retninger og paradigmer, om hvad der er acceptabel fremstillings- og argumentationsform på et universitet (mundtligt og/eller skriftligt). Typisk har denne konsensus kunnet ses, når bedømmerne har konsulteret karakterbekendtgørelsens uddybende bestemmelser i SS 4-7. Ja - begreber er nævnt, men man kan ikke se, at de også er tilegnet og forstået. Nej, sammenligning af begreber og teorier findes kun i sparsomt omfang. Måske der er forsøgt argumentation, men er den sket på den måde, man ville argumentere ved Moster Annas kaffebord, eller i forhold til de teoretiske synspunkter fremlagt i kilderne? Og så videre for de i alt 7 underpunkter i disse uddybende paragraffer.

Den akademiske konsensus man kan opleve i praksis kan beskrives således:

"når to eller flere parter, der ikke tidligere har drøftet regelsættet for bedømmelse med hinanden, og har forskellige daglige faglige præferencer, uden alvorlige problemer finder fælles argumenter med udgangspunkt i det fælles regelgrundlag i form af pensum og studieordningernes krav for, hvordan en præstation skal vurderes på karakterskalaen«

Der er tale om en sammenfatning af erfaringer - som er både positive og overraskende. Ikke om en teoretisk analyse. Mange er beretningerne fra censorer og eksaminatorer, der har været overraskede over, at en fagfælle med et velkendt anderledes fagligt udgangspunkt har forholdt sig fagligt åbent i vurderingen af en eksamenspræstation. Glæde over, at bedømmelsen har kunnet ske ansvarligt, på et sagligt grundlag.

Den akademiske konsensus er således hovedreglen. Alle parter finder sig rimeligt tilpas og føler sig rimeligt hørt, forstået og tilgodeset i forbindelse med bedøm- 
melsen, der opleves som at have været nogenlunde retfærdig. Men problemer findes.

Nogle af de mest markante belyses nedenfor. Den første type har at gøre med omdiskuterede bedømmelseskrav - individuel bedømmelse ved gruppeeksamen, og sidetalsbegrænsning. Andre problemer har at gøre med vanskeligheder med udmøntning af de faglige krav (typisk i forbindelse med karakterfastsættelsen). Den sidste type har at gøre med social pli og omgangsform, specielt ved mundtlig eksamen og mundtlig feedback på karaktergivningen.

\section{Omdiskuterede bedømmelseskrav}

Gruppeprover. En gruppe arbejder tæt sammen om en længerevarende skriftlig opgave med selvvalgt emne. De lærer af hinanden. De beriger hinanden. De skriver og retter gensidigt. Måske en eller to i gruppen bidrager mindre end andre. Ingen ved længere, hvem der har ansvar for hvilke ord i den skrevne tekst. Men teksten skal bedømmes individuelt. Eksaminator har fulgt deres proces, og har set, hvordan de har lært af hinanden, og har også selv bidraget aktivt med spark og udfordringer til denne læreproces.

Eksaminator og gruppe har således udgjort et fælles socialt system, der skal ændres fuldstændigt, når bedømmelsen skal finde sted. Gruppemedlemmerne skal bedømmes individuelt, og eksaminator er ikke længere coach og vejleder, men bedømmer. Censor kommer til - helt udefra. Har ikke været en del af denne fælles proces.

Der er sket forskelsbehandling af studerende ved rent skriftlige gruppeprøver. Det er forekommet, at de studerende slet ikke har angivet forfatternavn ved afsnit, så individuel bedømmelse ikke var mulig. Det er forekommet, at grupper har påberåbt sig ophavsretten til en linie eller en side hver på skift, afhængigt af antallet af gruppemedlemmer. Og det er forekommet, at ingen af bedømmerne har været opmærksom på det, men har læst teksten samlet, og på den baggrund givet en fælles karakter. Andre bedømmerpar har været opmærksomme, og har dumpet sådanne skriftlige præstationer. Der findes ingen opgørelse af omfanget af en sådan forskelsbehandling, men der er efterfølgende på psykologi indført kontrol med, at der fremover er en synlig og tydelig ansvarsfordeling ved skriftlige gruppeopgaver.Ved mundtlige gruppeprøver har tilsvarende problemer kunnet ses, men der er efterhånden tydelighed omkring nødvendigheden af at argumentere konkret for de afgivne karakterer for hver enkelt af de studerende, uanset om der er givet samme karakter til alle eller individuelle karakterer.

Sidetalsgrcenser.Ved alle eksaminer er der grænser for den studerendes udfoldelse - være sig mundtligt eller skriftligt. Sidetalsgrænser ved skriftlige hjemmeopgaver er beskrevet præcist i studieordningerne. Grænserne har både faglige begrundelser og praktisk-økonomiske begrundelser. De faglige begrundelser forankrer sig - på tværs af paradigmer og teoretiske retninger - i et akademisk ideal om at kunne kondensere formidlingen af sin viden inden for den ramme, der er stillet til rådighed. De praktiske begrundelser handler om aflønning, idet begge bedømmere er honoreret i henhold til de normerede timer for den pågældende bedømmelse.

Der burde således ikke være noget problem i praksis, men det har der været. Enten var bedømmerne ikke opmærksom på sidetallet, eller også var de uenige om konsekvenserne for karakteren af en mulig overskridelse. Et fătal bedømmere har lavet en manuel optælling af typeenheder på en teksttung side for at danne sig et skøn over overskridelsens omfang. Kontrol var således sjælden.

Reelt er der sket forskelsbehandling af studerende, der har overskredet det tilladte sidetal. Nogle bedømmere har reelt ikke været opmærksomme på sidetallet, især efter at PC blev mere almindeligt anvendt, så man ikke længere kunne forlade sig på sidetalsnummereringen. Andre bedømmere har givet op over for problemet, og ladet det passere. En del studerende har udvist layoutmæssig kreativitet med hensyn til at placere flere ord $\mathrm{i}$ et dokument, uden at sidetallet så ud til at være stærkt overskredet. Men i alle institutionerne er der nu indført krav om, at tekster med sidetalsbegrænsning skal indeholde dokumentkontrollens optælling af typeenheder, og en omregning til normalsider i henhold til studieordningens definition.

Begge disse problemer må antages at have deres rod $i$ en vis uenighed om de grundlæggende regelsæts formulering af kravene. Individuel bedømmelse ved gruppepræstationer har været debatteret intenst, fagligt og studenterpolitisk, i en lang årrække. Mens sidetalskravene har haft mindre debatopmærksomhed, og blot med PC'ens udbredelse kunnet liste sig ind og på et tidspunkt udgøre et egentligt problem i form af forskelsbehandling. Med enkle administrative procedurer er langt hovedparten af begge problemer væk i dag som kilde til forskelsbehandling i bedømmelsen - selv om der fortsat er forskellige holdninger til, om der skal være individuel bedømmelse, og om sidetalsbegrænsninger skal overholdes.

\section{Udmøntning af de faglige krav}

Den studerendes forstålse af de faglige krav. Klager over karakteren har typisk udgangspunkt i, at den studerende selv oplever at have opfyldt alle faglige krav til den pågældende eksamen langt bedre, end karakteren afspejler. I nogle tilfælde er det af klagematerialet tydeligt, at den studerendes forståelse af kriterier for akademisk analyse og diskussion er mangelfuld, og at en karakter øverst i middelområdet eller det højeste område, ikke er berettiget. At nævne et begreb eller en metode kortfattet opleves af nogle som tilstrækkelig dokumentation for en tilegnelse og forståelse. Analyse, 
diskussion og sammenligning er ikke foretaget på et niveau, der kunne berettige en højere karakter. I en del tilfælde påpeges dette af bedømmerne ved klagesvaret, men $i$ andre tilfælde overses det.

Relevante uklarheder blandt bedommerne. I andre tilfælde er der en vis usikkerhed hos bedømmerne om, hvordan det faglige skøn bør anlægges mht. krav om demonstration af bredde ved breddeafprovende eksaminer med selvvalgt emne. Hvor grundigt skal bredden demonstreres? Hvor tydeligt skal den selvstændige tilegnelse vises? Hvis den studerende har oplevelsen af ved sin egen afgrænsning af emnet at have fastlagt kriterierne for den faglige bedømmelse, og har overset, at eksamen er breddeafprøvende, har bedømmerne et særskilt problem med begrundelsen for karakterfastsættelsen. Den skal være omhyggeligt forankret i de regelsæt, der fastlægger breddeafprøvning som krav ved denne eksamensenhed.

Oplevelse af mobning. I de mest problematiske ankesager har de studerende en oplevelse af, at én eller begge bedømmere aktivt har modvilje mod denne som person, hvad enten der forud har været personlig kontakt eller ej. Føler sig misforstået og miskendt på et personligt grundlag og ikke et fagligt. I nogle af disse problematiske tilfælde findes også en oplevelse af, at en eller begge bedømmere ikke har faglige forudsætninger for at foretage bedømmelsen, eller ikke har forholdt sig opmærksomt til teksten eller den mundtlige præstation (fx oplevelsen af, at censor "sov" under eksaminationen).

De skrappe og de milde bedommere. Endelig er der den mindst konfliktfyldte del i denne type af problemer - nemlig, at det er velkendt, at nogle sammensætninger af bedømmerpar generelt vil give gennemsnitligt lidt lavere karakterer end andre sammensætninger. »De skrappe " og "de milde« bedømmere forholder sig alle seriøst til eksamenskravene, men tenderer til at ligge en anelse forskelligt i udmøntningen af karakterer. I en række tilfælde er det efter sådanne eksaminationer undersøgt, om der er statistisk signifikant forskel mellem forskellige bedømmerpar ved masseeksaminerne - det er ikke tilfældet. Inden for denne type problemer har det derfor ikke kunnet ses, at der har været egentlig forskelsbehandling af de studerende.Variationerne ligger alle inden for det, der tidligere er beskrevet som den akademiske konsensus. Der har ikke forekommet alvorlige svigt fra nogen af bedømmernes side, og der er generelt opmærksomhed på at sammensætning af bedømmerpar skal være så varieret som praktisk muligt.

\section{Social pli og omgangsform}

Med denne type problemer vender vi tilbage til hverdagslivets uformelle og uudtalte bedømmelser af hinanden, og de konflikter det kan medføre. Alle tre roller $i$ en bedømmelse er i risiko for at blive vurderet på denne måde - især i forbindelse med mundtlige eksaminer eller skriftlige eksaminer med mundtlig feedback og begrundelse for karaktergivningen.

Gensidig respektfuld adford. Primært bedømmerparret. Hvem kommer først til eksamenslokalet? Censor eller eksaminator? Hvem byder studerende velkommen? Hvem sikrer, at lokalet ser ryddeligt ud, og der er stole ved eksamensbordet og mulighed for at se hinanden? Kommer én uvarslet $i$ sidste sekund (eller endda for sent), så det er umuligt at nå at hilse på hinanden og roligt tage hul på eksaminerne? Er påklædningen neutral og enkel? Alt sammen småting, der kan få betydning for, hvordan de studerende oplever samarbejdet mellem bedømmerne, fordi de typisk er i god tid til en mundtlig eksamen, og holder øje med lokalet.

Tid til afstemning af krav. Bedømmerpar, der ikke før har været sammen, og derfor ikke har en fælles afstemt opfattelse af hverken krav eller proces, er nødt til at have tid til, at en sådan afstemning kan finde sted, inden en mundtlig eksamination begynder. Hvem tager initiativ til at aftale at mødes et kvarter før den første eksamen? Hvem spørger eller fortæller aktivt om forholdet mellem studieordningens krav og pensum? Hvem medbringer hvilke formelle regelsæe til bedømmelsen? Hvem tager initiativ til en afstemning af rolleforvaltningen ved eksaminationen (i psykologi er det eksaminator, der leder eksaminationen, og censor kan bidrage)? Hvem holder tiden? Hvem henter de studerende til den nye eksamination? Hvem lægger ud med begrundelser for karaktergivningen ved feedback? Hvem sikrer, at der er enighed om begrundelserne, så man ved feedback ikke begrunder i øst og vest, men supplerer hinanden? Uklarheder mellem bedømmerne af denne type er forholdsvis usynlige for de studerende, men ofte vil de blive fornemmet diffust, og især ved en række mundtlige eksaminer samme dag blive kommenteret og fortolket - måske overfortolket - af de ventende studerende.

Den nærliggende løsning på dette problem er at læse op på sin Emma Gad. Hun var sin tids socialpsykolog - omend ikke teoretiker. Hendes råd om social omgang i de borgerlige kredse var ikke anvisninger, der skulle følges til punkt og prikke, men byggede på virkelighedens observationer. Ideen var, at de skulle kunne forebygge ubehagelige overraskelse, som kunne sikre, at man ikke blev vurderet på tilfældige og utilsigtede fejl $\mathrm{i}$ den sociale omgang, men bevidst selv var ansvarlig for, at andre vurderede en på det grundlag man ønskede at blive vurderet på. Fejl forekommer alligevel - men selv fejl havde den kloge kone en række råd til hurtigt at få rettet op på.

De rent retlige problemer ved bedømmelser er enkle men tidkrævende at rette op på. De kræver institutionel indsats. De problemer, der alene har at gøre med social pli og omgangsform kan kun rettes op af de enkelte bedømmerpar og de enkelte studerende. Nemt oven i købet. Social pli i bedømmelses- 
sammenhæng er at finde en form for gensidigt og tydeligt at vise respekten for denne handling, samtidig med fælles at skabe en afslappet og neutral atmosfære for både eksamination og votering i enrum. Det er ikke nødvendigt med grønt klæde på eksamensbordet, men det er et signal, der tydeliggør respekten for selve eksamenshandlingen. Men andre signaler er lige så brugbare, hvis de er klare nok. Det er ikke social pli at udstille grundlæggende uenigheder, som ikke er forsøgt drøftet med god vilje i akademisk konsensus ved konsultation med det retlige grundlag. Det er ikke social pli at vise personlig irritation $i$ en mundtlig eksamen. Selv om karakterfastsættelsen sker i enighed, kan sådan udstilling af rolleforskelle medføre forestillinger om, at lige netop dette bedømmerpar i forhold til lige netop denne/disse studerende ikke har forholdt sig objektivt og nøgternt - at bedømmelsen ikke har været retfærdig.

\section{En retfærdig bedømmelse i en socialt kompleks sammenhæng}

Principperne for retfærdighed er forankret i regelsættene. Den udmøntes konkret i handling ved hver enkelt bedømmelse. Bedømmelsen finder sted i en socialt kompleks sammenhæng, hvor glidninger i teoretiske landvindinger og nyere dokumentation for teoriers bæredygtighed konstant vil udfordre det givne regelsæt. De tre parter i bedømmelsen har forskellige forudsætninger for at være ajour med disse helt grundlæggende glidninger. De studerende er - i sagens natur - længst fra hjertet af sådanne glidninger. Men også eksaminatorer og censorer kan være meget langt væk fra hinanden - selv institutionscensorer kan være langt væk fra kernen af de glidninger, der sker på den institution, de fungerer som censor på.

Enhver eksaminator har som opgave at meritere sig akademisk på den institution, vedkommende er ansat. Enhver censor (både institutions- og aftagercensorer) har ligeledes som opgave at meritere sig på sit ansættelsessteds egne præmisser.

Er de problemer, der viser sig med udmøntningen af de faglige krav dermed uløselige? Eller kan man gøre noget for at forebygge?

Personligt tror jeg, at det er muligt at forebygge, så oplevelsen af mobning, af uretfærdig bedømmelse, af store forskelle mellem milde og skrappe bedømmere, kan mindskes betydeligt. Grundlæggende kun ved, at institutionerne, de studerendes organisation og censorformandskaberne løbende påpeger de problemer, der findes - og sammen finder lokale bæredygtige løsninger, som respekteres og forstås af alle tre parter.

Fælles bæredygtige løsninger, som giver alle institutioner tydeligere rammer, kan kun findes gennem ændringer i lovgrundlag og bekendtgørelser. Men de har en trang vej, og vil ofte finde sted i et politisk klima, hvor kompromiser er nødvendige.
Samtidig skal hver enkelt bedømmer - eksaminator såvel som censor - finde deres egne tydelige og velforankrede pejlemærker i de ofte lidt forvirrende eller antydningsvist modstridende bestemmelser i regelsættet. Selv har jeg fundet et sæt pejlemærker, der har fungeret godt $\mathrm{i}$ forhold til den nuværende karakterbekendtgørelse. Når jeg har nævnt dem for mine bedømmerkolleger i forbindelse med problematiske voteringer, har de vundet genklang. Jeg har ikke ment, jeg kunne udbrede mine personlige pejlemærker i min funktion som censorformand, og dermed ophøje dem som overordnede over regelsættene. Alligevel vil jeg her, afslutningsvis delagtiggøre læserne $i$, hvad de består $i$ - som inspiration. Jeg har lavet mig en remse, der på engelsk rimer: naming, taming, reframing. Let at huske. Let at formidle til min medbedømmer. Et godt redskab til med hjælp i karakterbekendtgørelsens uddybende paragraffer at finde en karakter, der er enighed om, og som er let at begrunde. Naming handler om, at den studerende korrekt og kortfattet kan gengive en teori eller et begreb, der er centralt for opgavens formulering. Taming handler om, at den studerende kortfattet kan præsentere sin egen forstålse af dette (ikke andre kilders forståelse, men netop sin egen forståelse af forskellige kilders udlægninger). Reframing handler om, at den studerende selvstændigt har fundet et videnskabsteoretisk udgangspunkt for selvstændigt at vurdere ikke blot teorier og begreber og forskellige opfattelser af disse - men også eventuelle empiriske data. Ofte er der elementer af alle tre dele - ofte er der fejl på det elementære niveau, og kunnen og viden på de to mere avancerede niveauer. Men det sker, at der er fravær af de to mere avancerede niveauer.

Personlige pejlemærker er væsentlige - men de kan ikke stå over retsreglerne.Vi må leve med de usikkerheder, der er - men også bestræbe os på at mindske dem mest muligt. Delagtiggøre hinanden i vanskelighederne - udbrede denne viden til de studerende. Åbenhed om denne vanskelige proces.

\section{Efterskrift}

Efter indleveringen af denne artikel blev der bebudet ændring af to af de centrale regelsæt omkring eksamen. To bekendtgørelsesudkast sendes til høring i løbet af januar måned.

Eksamensbekendtgørelsen revideres (uklart på hvilken måde) med hensyn til adgangen til at gennemføre gruppeprøver. Om det er hele $\mathbb{S} 3$, der ændres, eller kun dele af den, vides ikke. I $₫ 3$ i den nuværende bekendtgørelse fastslås det utvetydigt, at der også ved gruppeprøver skal ske en individuel bedømmelse. Som jeg har beskrevet, er det langt enklere at sikre en individuel bedømmelse ved en mundtlig prøve end ved en rent skriftlig. Der er - for mig at se - derfor ikke bedømmelsesfagligt belæg for at afskaffe mundtlig gruppeprøve. Den velkendte konflikt har vist sig i pressen 
straks. Karakterbekendtgørelsen revideres fuldstændigt. Et betænkningsudvalg fremlagde et overordnet forslag til ny skala i efteråret 2004. Betænkningen havde arbejdet grundigt med selve skalaproblemet, og kun overordnet med de faglige beskrivelser af de forskellige karakterer. De bliver udmøntet nærmere i bekendtgørelsen. De gode erfaringer med specifikationerne i den nuværende karakterbekendtgørelses $\$ \int$ 'er 4-7 bør indarbejdes klart og tydeligt $\mathrm{i}$ den nye bekendtgørelse. Ellers er der betydelig risiko for, at universitetsstudierne står over for endnu en omfattende revision af studieordningerne, for at sikre tydelighed om, hvad de faglige krav er på et universitet. Studieordningerne er netop efter møjsommeligt arbejde revideret - men den revision er sket i lyset af den nuværende karakterbekendtgørelses hjælp til specifikation af kravene. Skal de nu på den igen? Og i en periode efterlade bedømmerne $i$ et "hul «, hvor der ikke blot er nye tal, men også mangler krav om begrebsbeherskelse, sammenligning af teorier mv.? Essensen af universitetsverdenens fælles krav på tværs af fag og retninger. Personligt håber jeg det ikke. Jeg håber, at den nye bekendtgørelse giver denne hjælp til forståelsen af tallene. 